NBER WORKING PAPER SERIES

GLOBALIZATION POLICIES AND ISRAEL'S BRAIN DRAIN

\author{
Assaf Razin \\ Working Paper 23251 \\ http://www.nber.org/papers/w23251 \\ NATIONAL BUREAU OF ECONOMIC RESEARCH \\ 1050 Massachusetts Avenue \\ Cambridge, MA 02138 \\ March 2017
}

The views expressed herein are those of the author and do not necessarily reflect the views of the National Bureau of Economic Research.

NBER working papers are circulated for discussion and comment purposes. They have not been peer-reviewed or been subject to the review by the NBER Board of Directors that accompanies official NBER publications.

(C) 2017 by Assaf Razin. All rights reserved. Short sections of text, not to exceed two paragraphs, may be quoted without explicit permission provided that full credit, including $\odot$ notice, is given to the source. 
Globalization Policies and Israel's Brain Drain

Assaf Razin

NBER Working Paper No. 23251

March 2017

JEL No. F22,H1,J11

\title{
ABSTRACT
}

The paper links Israel's brain drain to skill-based immigration policies, prevailing in the advanced economies.

\author{
Assaf Razin \\ Eitan Berglas School of Economics \\ Tel Aviv University \\ Tel Aviv 69978 \\ ISRAEL \\ and Cornell University and CEPR \\ and also NBER \\ ar256@cornell.edu
}




\section{Globalization Policies and Israel's Brain Drain}

by

Assaf Razin

March 2017

\section{Abstract}

The paper links Israel's brain drain to skill-based immigration policies, prevailing in the advanced economies.

Economic basic principles imply that both low-skill and high-skill immigration enrich the workforce, thereby allow for a more finely graded specialization that raises average productivity, and living standards. Diverse workforces are likely to be more productive, especially in industries where success depends on specific knowledge, such as computing, health care and finance. By easing labor bottlenecks, migrants help to keep down prices of goods and services.

However, in the confines of the generous welfare state, low skill immigrants impose fiscal burden on the native born. In contrast, high-skill immigrants help in relieving the burden. This is the economic rationale behind skill-based immigration policies. The other side of the skill bias in immigration policy is that the international migration of skilled workers (the so-called brain drain) deprives the origin country from its scarce resource-human capital. In setting up a migration policy, one is certainly concerned by the skill composition of immigrants is a crucial factor. Naturally, highly- skilled immigrants are more attractive to the destination countries than 
low-skilled, immigrants for a variety of reasons are. For instance, highly- skilled immigrants are expected to pay more in taxes to the Fisc in excess of what the Fisc provides them with. In addition, these immigrants are also expected to boost the technological edge of their destination countries. In contrast, low-skilled immigrants tend to depress the low-skill wages of the nativeborn, and they are deemed to impose a burden on the fiscal system.

The skill composition of immigrants to OECD countries other than the US, Australia, Canada and Ireland is skewed towards the low education group, thanks to the less rigorous screening of immigration policies. Australia, Canada, and US high-skill biased policy is shown in Table $1^{1}$.

\footnotetext{
${ }^{1}$ Razin and Sadka (2014) argue that the differences between the U.S. and the EU relate to the degree of fiscal and migration coordination among the member states of the economic unions ( EU vs US) and the difference in the aging of the population between them.
} 
Table 1: Skill composition of immigration

\begin{tabular}{|c|c|c|}
\hline $\begin{array}{l}\text { Country of } \\
\text { Immigration }\end{array}$ & $\begin{array}{l}\text { Low Education as } \\
\% \text { of total } \\
\text { Immigration } \\
\text { in } 2000^{1}\end{array}$ & $\begin{array}{l}\text { High Education as } \\
\% \text { of total } \\
\text { Immigration in } \\
2000^{1}\end{array}$ \\
\hline Austria & 47.5 & 12.7 \\
\hline Belgium & 65.7 & 18.3 \\
\hline Denmark & 44.8 & 17.3 \\
\hline Finland & 48.7 & 23.8 \\
\hline France & 74.6 & 16.4 \\
\hline Germany & 65.9 & 21.8 \\
\hline Greece & 44.5 & 15 \\
\hline Ireland & 13.6 & 41.1 \\
\hline Italy & 52.9 & 15.4 \\
\hline Netherlands & 50.2 & 22 \\
\hline Norway & 22 & 28.7 \\
\hline Portugal & 59.7 & 18.6 \\
\hline Spain & 28.7 & 18.5 \\
\hline Sweden & 34.1 & 25.7 \\
\hline Switzerland & 54.9 & 18.6 \\
\hline UK & 34.1 & 34.9 \\
\hline $\begin{array}{l}\text { Average } \\
\text { EUROPE }\end{array}$ & 46.37 & 21.8 \\
\hline Australia & 35.3 & 40.3 \\
\hline Canada & 29.6 & 58.8 \\
\hline USA & 37.9 & 42.7 \\
\hline $\begin{array}{l}\text { Average AUS, } \\
C A N \& U S\end{array}$ & 34.27 & 47.27 \\
\hline
\end{tabular}

Sources: Docquier and Marfouk (2006).

${ }_{\text {A Universities and collegss are the other important gatekeeners through their selection ff }}^{2}$ indors is US research centers. US universities and research centers, funded directly and indirectly by the US federal and state governments, attract talented researchers from all over the world. Many 
The paper is organized as follows. Section 1 provides some theoretical underpinnings of highskill based immigration policy. Section 2 apply the model to analyze, empirically, key determinants of the skill composition of immigration to the advanced economies. Section 3 describes brain drain in selected group of countries. Section 4 concludes with the discussion of Israel's top-talent drain.

\section{Understanding the Essence of Skill-Based Immigration Policy}

How does the size of the welfare state affect the skill composition of immigration? A more generous welfare state is more attractive to low-skilled immigrants, known as the magnet effect (Borjas 1999). This is a supply-side explanation for the different composition of immigrants in the US and Europe. Europe, with its generous welfare states, is an attractive destination for lowskilled immigrants, but far less so for high-skilled immigrants who are likely to be net fiscal contributors. Indeed, the demand for immigrants, however, goes in the opposite direction. A more generous welfare state (particularly with an aging population) has financing needs that

individuals for the F1 (student) or J1 (exchange visitor) visas (see Kerr et al (2016)). While these visas do not offer long-term employment, US firms often recruit graduates of US schools using visas like the $\mathrm{H}-1 \mathrm{~B}$. An advantage of employment-based immigration- policy regime compared to a points-based approach is that the job-market search process is more efficient in the former case. The employer-employee match is guaranteed to connect the immigrant talent with a productive and adequate job. 
immigrants could fill. With high-skilled immigrants more likely to pay in rather than draw on the welfare state, more generous welfare states are more inclined to try to attract high skilled. 3

To highlight skill-migration demand side forces I present a minimalist model that features two migration regimes: free-migration and policy-controlled migration regimes. In summary, the policy-controlled migration regime leads to a positive effect of the welfare benefits on the skill composition of migration rates, because voters will internalize the fact that skilled migrants will be net contributors to the system (i.e., the fiscal burden effect), whereas unskilled migrants will be net beneficiaries (i.e., the social magnet effect). Under the free-migration regime, unskilled migrants will gravitate to a generous welfare state, while skilled migrants will be deterred.

I assume a Cobb-Douglas production function, with two labor inputs, skilled and unskilled:

$$
Y=A L_{\mathrm{e}}^{\alpha} L_{\mathrm{u}}^{1-\alpha}, \quad 0<\alpha<1 .
$$

Here, $Y$ is the GDP, $A$ denotes a Hicks-neutral productivity parameter, and $L_{i}$ denotes the input of labor of skill level $i$, where $i=\mathrm{e}$, u for skilled and unskilled, respectively. Wages, $w_{i}$, are competitive and equal to the marginal productivity of $L_{i}$.

Aggregate labor supply, for skilled and unskilled workers, respectively, is given by

\footnotetext{
${ }^{3}$ Why have European countries been unsuccessful in either encouraging high-skill immigration or in limiting the size of their welfare state? Razin and Sadka (2014) take a page out of the vast work on tax competition to provide insights. They argue that fiscal independence in a migration union like Schengen leads to policy distortions. Schengen members do not fully internalize the degree to which their generous welfare states attract immigrants, as the costs of immigration are borne by the union as a whole. This the need for fiscal unity in a common immigration zone is novel. See Ilzetzki (2016).
} 


$$
\begin{gathered}
L_{\mathrm{e}}=(e+\sigma \mu) l_{\mathrm{e}}, \\
L_{\mathrm{u}}=[1-e+(1-\sigma) \mu] l_{\mathrm{u}^{*}} .
\end{gathered}
$$

Here, $l_{i}$ denotes the individual labor supply, $e$ denotes the share of native-born skilled workers in the total native-born labor supply, $\sigma$ denotes the share of skilled migrants in the total number of migrants, $\mu$ denotes the total number of migrants, and is the labor supply of an individual with skill level i, . The total population $(N)$ is comprised of native-born workers (which is normalized to 1) and migrants $(\mu)$.

We specify a simple welfare-state system, which levies a proportional labor income tax at the rate $\tau$, with the revenues redistributed equally to all residents, $N$, as social benefit per capita, $b$. The social benefit captures not only a cash transfer but also outlays on public services, such as education, health, and other provisions, which benefit all workers, regardless of their contribution to the tax revenues.

The government budget constraint is therefore

$$
N b=\tau Y .
$$

Assume that the utility function for skill type $\mathrm{i}, i \in\{\mathrm{e}, \mathrm{u}\}$, is

$$
u_{i}=c_{i}-\frac{\varepsilon}{1+\varepsilon} l_{i}^{(1+\varepsilon) / \varepsilon},
$$

Where $c_{i}$ denotes consumption of an individual with skill level $i, l_{i}$ denotes the individual labor supply, and $\varepsilon>0$. The budget constraint of an individual with skill level $i$ is

$$
c_{i}=b+(1-\tau) l_{i} w_{i}
$$

Individual utility-maximization yields the following labor supply equation: 


$$
l_{i}=\left[(1-\tau) w_{i}\right]^{\varepsilon} .
$$

The general equilibrium wages for skilled and unskilled workers are

$$
\begin{aligned}
& w_{\mathrm{e}}=A\left(\alpha \delta^{\varepsilon} \theta^{1-\alpha}\right)^{1 /(1+\varepsilon)}, \\
& w_{11}=A\left[(1-\alpha) \delta^{\varepsilon} \theta^{-\alpha}\right]^{1 /(1+\varepsilon)},
\end{aligned}
$$

Where,

$$
\begin{gathered}
\delta \equiv \alpha^{\alpha}(1-\alpha)^{1-\alpha}, \text { and } \\
\theta \equiv[1-e+(1-\sigma) \mu] /(e+\sigma \mu) .
\end{gathered}
$$

The host-country migration policy is to be determined by the median voter in the host country. Let us assume that the policy decisions on the tax rate $\tau$ and the total volume of migration $\mu$ are exogenous. We do this in order to focus the analysis on a single endogenous policy variable, which is the skill composition of migrants (i.e., $\sigma$ ). Note that once $\sigma, \mu$, and $\tau$ are determined, then the social benefit per capita, $b$, is given by the government budget constraint. Thus, we denote the social benefit per capita, $b$, as $b(\sigma ; \tau)$, where the exogenous variable $\mu$ is suppressed.

The indirect utility of an individual with skill level $i$ is given by

$$
V_{i}(\sigma ; \tau)=b(\sigma ; \tau)+\frac{1}{1+\varepsilon}\left[(1-\tau) w_{i}(\sigma ; \tau)\right]^{1+\varepsilon} .
$$

Differentiating the equation with respect to $\sigma$, and employing the envelope theorem, yields

$$
\frac{\mathrm{d} V_{i}(\sigma ; \tau)}{\mathrm{d} \sigma}=\frac{\mathrm{d} b(\sigma ; \tau)}{\mathrm{d} \sigma}+(1-\tau) l_{i}\left[w_{i}(\sigma ; \tau)\right] \frac{\mathrm{d} w_{i}(\sigma ; \tau)}{\mathrm{d} \sigma}
$$

Thus, a policy-induced change in the share of skilled migrants in the total number of migrants, $\sigma$, affects the utility level through two channels. First, an increase in $\sigma$ raises average labor productivity and thereby tax revenues. This, in turn, raises the social benefit per capita, $b$. 
Second, an increase in $\sigma$, which raises the supply of skilled labor relative to the supply of unskilled labor, depresses the skill premium in the labor market. If the decisive voter is unskilled, both of the above effects increase his utility. Thus, an unskilled voter would like to set the skill composition of migrants at the maximal limit, $\sigma=1$. This means that the share of skilled migrants preferred by the decisive skilled voter is typically lower than that preferred by the decisive unskilled voter. The decisive skilled voter would like to set $\sigma$ below 1 (which is equivalent to assuming that the first-order condition is met before $\sigma$ reaches 1).

Let superscript $i$ denote the choice of the skill mix of immigrants by a decisive voter $i ; i=u, e$. Define $\sigma^{i}$ as the share of skilled immigrants most preferred by an individual with skill level $i=\mathrm{e}, \mathrm{u}$ in the host country, we obtain

$$
\sigma^{\mathrm{e}}<\sigma^{\mathrm{u}}=1 .
$$

Recall that the purpose is to find the effect of the change in the generosity of the welfare state on the migration policy concerning $\sigma$. The generosity of the welfare state, captured by the magnitude of the social benefit per capita, $b$, depends positively on the tax rate, $\tau$ (we assume that the economy is on the "correct side" of the Laffer curve). Thus, we examine the effect of an increase in $\tau$ on the change in the skill composition of the migrants, $\sigma$. It can be shown that

$$
\frac{\mathrm{d} \sigma^{\mathrm{u}}}{\mathrm{d} \tau}=0 ; \quad \frac{\mathrm{d} \sigma^{\mathrm{e}}}{\mathrm{d} \tau}>0 .
$$

$$
\frac{d \sigma^{u}}{d A}=0, \operatorname{sign} \frac{d \sigma^{e}}{d A}=? .
$$

This means that, if the decisive voter were an unskilled worker, an increase in the tax rate $\tau$ would leave the skill migration policy unchanged, because it is always set at the maximum possible limit. However, if the decisive voter is a skilled worker, an increase in the tax rate $\tau$ will change the policy concerning the skill composition of migrants in the direction towards a larger 
share of skilled migrants. The reason for this is that when the tax rate is higher, the redistribution burden upon a skilled decisive voter increases. Allowing an additional skilled migrant can ease this rise in the fiscal burden. Note also that the result applies to the skill mix of migration rates.

Under skill native-born control, the effect of domestic productivity increase on the skill mix of immigration is to improve the mix, ( $\operatorname{sign} \frac{d \sigma^{e}}{d A}=$ ?). On one hand, the increase in the wage premium also raises tax revenues and eases the fiscal burden. This force makes unskilled migrants less burdensome to the Fisc. At the same time the increase in productivity also raises the efficiency gains, and mitigate the of the skill-labor wage, which makes the influx of skilled migrants desirable.

\section{Skill Composition of Immigration: Empirical Analysis}

While immigration from poor countries often invokes images of large masses of unskilled laborers, in reality it has been quite skill-intensive. The composition of immigrants into highincome countries, even if they originate from countries with lower income per person, tends to be more concentrated among highly educated than among less educated, relative to the population of the country of destination (see Peri (2016)).

The explanation for the concentration of rich-country immigrants among the highly educated is the screening and selection migration policies by the destination countries.

In this context, Razin and Wahba (2015) researched two hypotheses associated with migration skill mix: The fiscal burden hypothesis and the magnet hypothesis. The former asserts that under host-country migration policy, the rise in the generosity of the welfare state will skew the skill mix towards skilled migrants because they can ease fiscal burden. The second hypothesis asserts 
that under free migration, would be low skilled migrants will be more attracted to the welfare state so that a more generous welfare state will have its skill mix skewed towards the low skilled migrants. Accordingly, they investigate the effect of welfare state generosity on the difference between skilled and unskilled migration rates, and the role of mobility restriction in shaping this effect. They utilize the free labor movement within the European Union plus Norway and Switzerland (EUROPE) and the restricted movement from outside the EUROPE in order to compare the free-migration regime to the controlled-migration regime. Using bilateral migration movements, and splitting the sample among flows within EUROPE, and flows from outside EUROPE, they identify the migration regime effect. In Table 2 the dependent variable is the share of skilled migrants in the migrant population, and the main explanatory variable is "benefits per capita" - a measure of the generosity of the welfare state. The hypothesis is that under free migration the coefficient of this variable is negative whereas under controlled migration coefficient of "benefits per capita multiplied by $\mathrm{R}$ " is positive. The indicator $\mathrm{X}$ is a dummy variable: $\mathrm{R}=1$, if migration is controlled, whereas $\mathrm{R}=0$, if migration is free. Recall the bi lateral migration flows within EUROPE are referred to as free migration, whereas bi lateral migration flows where the SOURCE is outside and the DESTINATION is inside EUROPE are referred to as controlled migration. Appendix 10A includes some robustness tests of the model. 
Table 2: Skill Composition of Immigration: OLS Estimates

Dependent Variable: Skill Difference in Migration Rates in 2000

Welfare generosity
\begin{tabular}{|c|c|c|c|c|c|c|}
\multicolumn{3}{c|}{$\begin{array}{c}\text { EUR \& DC } \\
\text { to EUR }\end{array}$} & \multicolumn{3}{c|}{ EUR \& LDC } \\
\hline benefits per capita (logs) & -0.110 & -0.112 & -0.116 & -0.115 & -0.136 & -0.131 \\
$1974-90$ (host) & $(0.057)^{*}$ & $(0.056)^{* *}$ & $(0.047)^{* *}$ & $(0.056)^{* *}$ & $(0.053)^{* *}$ & $(0.047)^{* * *}$ \\
\hline benefits per capita (logs) & 0.113 & 0.137 & 0.132 & 0.102 & 0.101 & 0.110 \\
$1974-90$ (host) X R & $(0.053)^{* *}$ & $(0.064)^{* *}$ & $(0.055)^{* *}$ & $(0.065)$ & $(0.079)$ & $(0.066)^{*}$ \\
\hline
\end{tabular}

\section{Lagged migration}

rates

\begin{tabular}{|c|c|c|c|c|c|c|}
\hline $\begin{array}{c}\text { low-skilled migration } \\
\text { rate } \\
1990\end{array}$ & $\begin{array}{c}-0.719 \\
(0.133) * * *\end{array}$ & $\begin{array}{c}-0.719 \\
(0.129) * * *\end{array}$ & $\begin{array}{c}-0.710 \\
(0.140) * * *\end{array}$ & $\begin{array}{c}-0.612 \\
(0.128) * * *\end{array}$ & $\begin{array}{c}-0.611 \\
(0.129)^{* * *}\end{array}$ & $\begin{array}{c}-0.609 \\
(0.137)^{* * * *}\end{array}$ \\
\hline $\begin{array}{c}\text { low-skilled migration } \\
\text { rate } \\
1990 \times \mathrm{R}\end{array}$ & $\begin{array}{c}1.723 \\
(0.173) * * *\end{array}$ & $\begin{array}{c}1.751 \\
(0.169)^{* * *}\end{array}$ & $\begin{array}{c}1.723 \\
(0.171)^{* * *}\end{array}$ & $\begin{array}{r}0.278 \\
(0.196)\end{array}$ & $\begin{array}{c}0.560 \\
(0.234)^{* *}\end{array}$ & $\begin{array}{c}0.552 \\
(0.226)^{* *}\end{array}$ \\
\hline $\begin{array}{c}\text { high-skilled migration } \\
\text { rate } \\
1990\end{array}$ & $\begin{array}{c}1.062 \\
(0.150)^{* * * *}\end{array}$ & $\begin{array}{c}1.061 \\
(0.147)^{* * *}\end{array}$ & $\begin{array}{c}1.049 \\
(0.155)^{* * * *}\end{array}$ & $\begin{array}{c}0.963 \\
(0.145) * * *\end{array}$ & $\begin{array}{c}0.959 \\
(0.146) * * *\end{array}$ & $\begin{array}{c}0.957 \\
(0.153) * * *\end{array}$ \\
\hline $\begin{array}{c}\text { high-skilled migration } \\
\text { rate } \\
1990 \times \mathrm{R}\end{array}$ & $\begin{array}{c}-0.725 \\
(0.149) * * *\end{array}$ & $\begin{array}{c}-0.726 \\
(0.144)^{* * *}\end{array}$ & $\begin{array}{c}-0.712 \\
(0.151)^{* * *}\end{array}$ & $\begin{array}{c}-0.481 \\
(0.157)^{* * *}\end{array}$ & $\begin{array}{c}-0.627 \\
(0.170)^{* * *}\end{array}$ & $\begin{array}{c}-0.623 \\
(0.173) * * *\end{array}$ \\
\hline
\end{tabular}

\section{Returns to skills}

\begin{tabular}{|c|c|c|c|c|}
\hline $\begin{array}{l}\text { high-low labor ratio in } \\
1990 \text { - (host) }\end{array}$ & $\begin{array}{c}-0.484 \\
(0.237)^{* *}\end{array}$ & & $\begin{array}{c}0.309 \\
(0.326)\end{array}$ & \\
\hline $\begin{array}{l}\text { high-low labor ratio in } \\
1990 \text { (host) X F }\end{array}$ & $\begin{array}{c}0.309 \\
(0.500)\end{array}$ & & $\begin{array}{c}0.019 \\
(0.656)\end{array}$ & \\
\hline $\begin{array}{l}\text { high-low wage diff. in } \\
1995 \text { (host) }\end{array}$ & & $\begin{array}{c}0.003 \\
(0.002)\end{array}$ & & $\begin{array}{c}0.001 \\
(0.003)\end{array}$ \\
\hline $\begin{array}{l}\text { high-low wage diff. in } \\
1995 \text { - (host) X F }\end{array}$ & & $\begin{array}{c}-0.007 \\
(0.003)^{* *}\end{array}$ & & $\begin{array}{c}-0.005 \\
(0.003)^{*}\end{array}$ \\
\hline Gini in 1990 (source) & $\begin{array}{c}0.012 \\
(0.004)^{* * *} *\end{array}$ & $\begin{array}{c}0.013 \\
(0.004) * * *\end{array}$ & $\begin{array}{c}0.011 \\
(0.004)^{* *}\end{array}$ & $\begin{array}{c}0.011 \\
(0.005)^{* *}\end{array}$ \\
\hline $\begin{array}{c}\text { Gini in } 1990 \text { (source) } \\
\text { X R }\end{array}$ & $\begin{array}{c}-0.012 \\
(0.005) * * *\end{array}$ & $\begin{array}{c}-0.014 \\
(0.005)^{* * *}\end{array}$ & $\begin{array}{c}-0.010 \\
(0.005)^{* *}\end{array}$ & $\begin{array}{c}-0.010 \\
(0.005)^{*}\end{array}$ \\
\hline
\end{tabular}




\begin{tabular}{|c|c|c|c|c|c|c|}
\hline $\begin{array}{c}\text { High-low unemp. rate } \\
\text { diff. } \\
\text { in } 1990 \text { (host) }\end{array}$ & 0.002 & 0.001 & & 0.003 & 0.006 \\
\hline $\begin{array}{c}\text { High-low unemp. rate } \\
\text { diff. } \\
\text { in } 1990 \text { - (host) X F }\end{array}$ & $(0.002)$ & $(0.002)$ & & $(0.002)$ & $(0.002)$ \\
\hline
\end{tabular}

Immigration policies

\begin{tabular}{|c|c|c|c|c|c|c|}
\hline $\begin{array}{c}\text { Total migrant stock } \\
\text { in } 1990\end{array}$ & $\begin{array}{c}-0.001 \\
(0.001)\end{array}$ & $\begin{array}{c}-0.001 \\
(0.001)\end{array}$ & $\begin{array}{c}-0.001 \\
(0.001)\end{array}$ & $\begin{array}{c}-0.002 \\
(0.001)^{* * *}\end{array}$ & $\begin{array}{c}-0.002 \\
(0.001)^{* * *}\end{array}$ & $\begin{array}{c}-0.002 \\
(0.001)^{* *}\end{array}$ \\
\hline $\begin{array}{c}\text { Share of refugees in } \\
1990\end{array}$ & -2.079 & -1.023 & -3.904 & -0.238 & -1.945 & -1.297 \\
& $(2.803)$ & $(3.237)$ & $(3.403)$ & $(2.145)$ & $(2.477)$ & $(3.007)$ \\
\hline Observations & 384 & 384 & 360 & 601 & 570 & 534 \\
\hline R-squared & 0.864 & 0.870 & 0.874 & 0.832 & 0.809 & 0.814 \\
\hline
\end{tabular}

Notes: F=Free migration; $\mathrm{R}=$ Restricted migration. Regressions include log distance, dummy for same language in host and source, strong dummy between host and source, \& real GDP per capita in host and in source countries. Robust standard errors in parentheses; * significant at $10 \%$; ** significant at 5\%; *** significant at $1 \%$.

In the regression analysis (see also the Appendix) Razin and Wahba (2015) control for differences in educational quality and returns to skills in source and host countries, and for endogeneity bias (by using instrumental variables). Overall, the fiscal burden and the magnet hypotheses, tested with the coefficient of social benefit in the regressions, are statistically significant. ${ }^{4}$ Therefore, regression findings yield support for the magnet hypothesis under the free-migration regime, and to the fiscal burden hypothesis, under the restricted-migration regime.

\footnotetext{
${ }^{4}$ See Appendix A for robustness tests.
} 


\section{Brain Drain: international comparison}

Kerr et al (2016) observe that the number of migrants with a tertiary degree rose by nearly 130 percent from 1990 to 2010, while low-skill (primary educated) migrants increased by only 40 percent during that time. High-skilled migrants are departing from a broader range of countries and heading to a narrower range of countries - in particular, to the United States, the United Kingdom, Canada, and Australia. ${ }^{5}$ At the policy level, they compare the points-based skilled migration regimes as historically implemented by Canada and Australia with the employmentbased policies used in the United States through visa-control mechanisms, like the $\mathrm{H}-1 \mathrm{~B}$ visa program. Because of the links of global migration flows to employment and higher education opportunities, firms and universities also act as important conduits, making employment and admission decisions that deeply affect the patterns of high-skilled mobility.

Gould and Moav (2007) focus on 28 countries, which represent the largest exporters of immigrants to the United States. The sample includes mostly advanced economies. Table 2 shows that the average index of emigration, (i.e., the number of emigres per 10,000 residents) is 33.36, with the index for Israel being nearly three times as high: 95.51. Only two countries have a higher index-Ireland (143.9) and Portugal (99.21). When examining the index for educated émigrés, i.e., those with a college degree, the average index is 12.41 and Israel's index is more than three times higher, 41.45. Using this index, Israel is now higher than Portugal and the gap between Israel and Ireland (49.09) narrows considerably. (See Table 8.2).

\footnotetext{
${ }^{5}$ Kerr et al (2015) give suggestive examples showing how global migration may be most pronounced for those at the very outer tail of the talent distribution.
} 
Table 3 presents international indicators selective indicators of Emigration to the US by Education Attainment. Israel is ranked at the very top for college graduate emigres per 10000 residents to the US; with number of about 41; only Ireland with a number 49 is ranked above Israel. South Korea, suffering also from brain drain, has only about 25 college graduate emigres per 10000 of its residents. 
Table 3: Indicators of Emigration to the US by Education Attainment

\begin{tabular}{|l|l|l|l|l|l|l|}
\hline $\begin{array}{l}\text { Country of } \\
\text { origin }\end{array}$ & $\begin{array}{l}\text { Number } \\
\text { of } 30-50 \\
\text { years } \\
\text { old } \\
\text { emigres }\end{array}$ & $\begin{array}{l}\text { Percentage } \\
\text { college } \\
\text { graduates }\end{array}$ & $\begin{array}{l}\text { Number } \\
\text { of college } \\
\text { graduates }\end{array}$ & $\begin{array}{l}\text { Population of } \\
\text { country of } \\
\text { origin }\end{array}$ & $\begin{array}{l}\text { Emigres } \\
\text { for } \\
10000 \\
\text { residents }\end{array}$ & $\begin{array}{l}\text { College } \\
\text { graduate } \\
\text { emigres } \\
\text { per } \\
10000 \\
\text { residents }\end{array}$ \\
\hline Denmark & 10,275 & 52 & 5,329 & $5,368,854$ & 19.14 & 9.93 \\
\hline Finland & 8,170 & 55 & 4,487 & $5,172,033$ & 15.80 & 8.68 \\
\hline Norway & 9,030 & 55 & 4,943 & $5,183,545$ & 17.42 & 9.54 \\
\hline Sweden & 17,174 & 56 & 9,584 & $8,876,744$ & 19.35 & 10.80 \\
\hline Great Britain* & 307,694 & 42 & 128,600 & $59,778,002$ & 51.47 & 21.51 \\
\hline Ireland & 55,877 & 34 & 19,061 & $3,883,159$ & 143.90 & 49.09 \\
\hline Belgium & 12,034 & 53 & 6,397 & $10,274,595$ & 11.71 & 6.23 \\
\hline France & 89,213 & 47 & 42,323 & $59,765,983$ & 14.93 & 7.08 \\
\hline Netherlands & 34,318 & 49 & 16,691 & $16,067,754$ & 21.36 & 30.39 \\
\hline Switzerland & 17,295 & 60 & 10,300 & $7,301,994$ & 23.69 & 14.11 \\
\hline Greece & 70,825 & 27 & 19,366 & $10,645,343$ & 66.53 & 18.19 \\
\hline Italy & 147,789 & 27 & 39,532 & $57,715,625$ & 25.61 & 6.85 \\
\hline Portugal & 100,044 & 10 & 9,700 & $10,084,245$ & 99.21 & 9.62 \\
\hline Spain & 46,564 & 39 & 18,020 & $40,077,100$ & 11.61 & 4.50 \\
\hline Austria & 15,936 & 43 & 6,877 & $8,169,929$ & 19.51 & 8.42 \\
\hline Czechoslovakia & 19,990 & 41 & 8,230 & $10,256,760$ & 19.49 & 8.02 \\
\hline Germany & 429,158 & 34 & 145,130 & $83,251,851$ & 51.55 & 17.43 \\
\hline Hungary & 20,498 & 39 & 7,969 & $10,075,034$ & 20.35 & 7.91 \\
\hline Poland & 176,737 & 27 & 47,587 & $38,625,478$ & 45.76 & 12.32 \\
\hline Romania & 48,294 & 43 & 20,877 & $22,317,730$ & 21.64 & 9.35 \\
\hline USSR/Russia & 271,364 & 53 & 143,202 & $144,978,573$ & 18.72 & 9.88 \\
\hline China & 709,415 & 55 & 387,900 & $1,284,303,705$ & 5.52 & 3.02 \\
\hline Japan & 225,484 & 48 & 108,981 & $126,974,628$ & 17.76 & 8.58 \\
\hline South Korea & 388,783 & 45 & 173,128 & $70,548,195$ & 55.11 & 24.54 \\
\hline Thailand & 57,733 & 35 & 19,987 & $62,354,402$ & 9.27 & 3.21 \\
\hline India & 667,434 & 65 & 432,037 & $1,045,845,226$ & 6.38 & 4.13 \\
\hline Israel/Palestine & 57,589 & 43 & 24,994 & $6,029,529$ & 95.51 & 41.45 \\
\hline Turkey & 39,649 & 45 & 17,974 & $67,308,928$ & 5.89 & 2.67 \\
\hline
\end{tabular}

England, Scotland and Wales.*

Source: Gould and Moav (2007). 


\section{Israel's Brain Drain}

US serves as a magnet for top scientific immigrants. US immigrants hold a disproportionate share of jobs in science, technology, engineering, and math (STEM) occupations in the United States (see Hanson and Slaughter (2016)). Top talent drain from Israel is disproportionately high among the high-end immigrants.

In general, the ratio of foreign scholars in America to scholars in the home country ranged from $1.3 \%$ in Spain to $4.3 \%$ in the Netherlands (Figure 1). At $12.2 \%$, Canada was an outlier, though this is much more of a two-way street than in any of the other cases. While Canada is an outlier, Israeli scholars in America are in a class by themselves. The Israeli academics residing in the States in 2003-2004 represented 24.9\% of the entire senior staff in Israel's academic institutions that year - twice the Canadian ratio and over five times the ratio in the other developed countries.

Figure 1 describes the percentage of home country academic scholars who have academic position in US universities. Figure 2 similarly describes Israel scholars in percentage of Israel Universities' senior faculty) in in the top US universities. 
Figure 1: Foreign Scholars in U.S. Universities, as percent of academic scholars in home country, 2003-2004

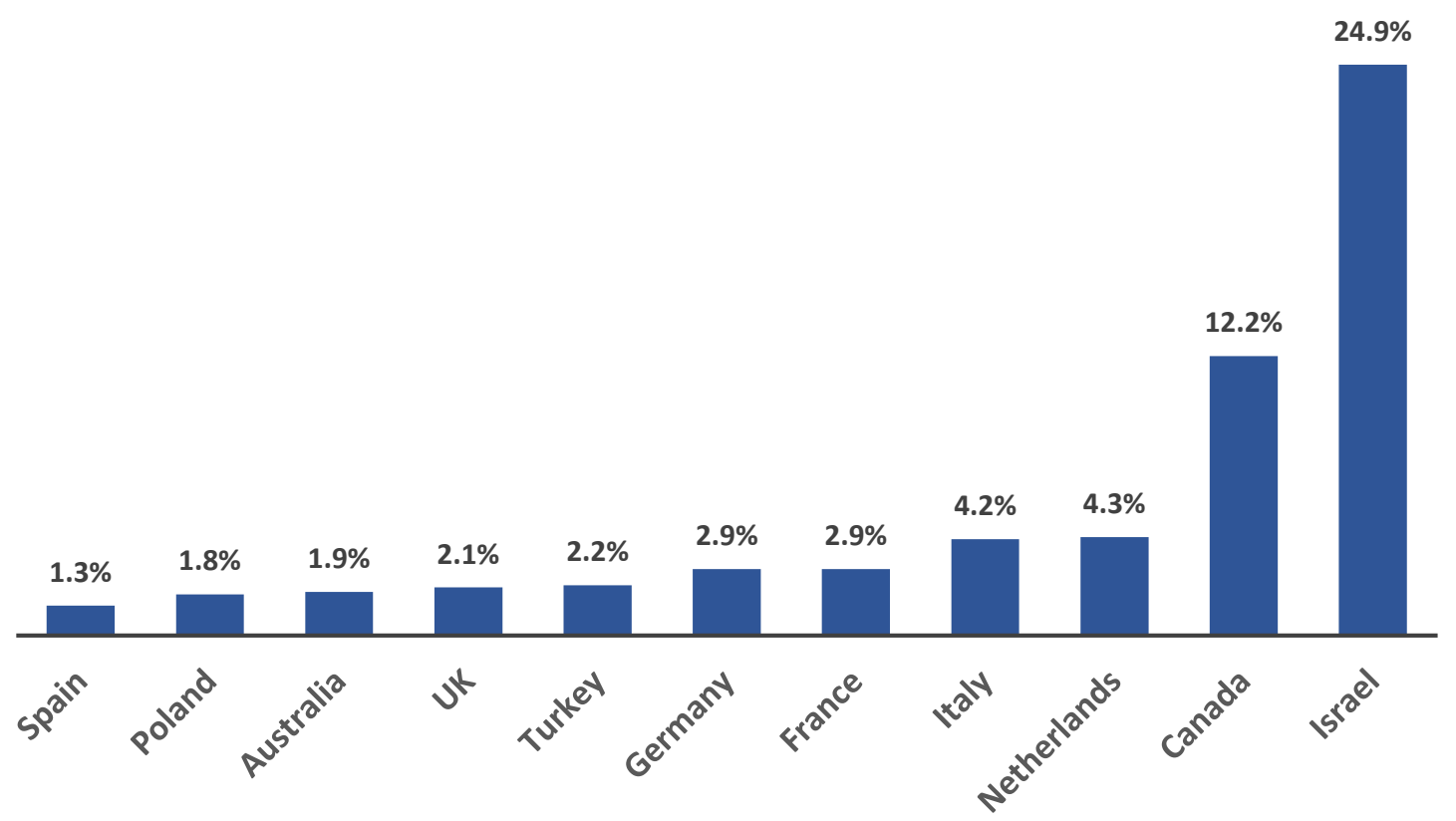

Source: Ben-David Dan (2008)

Israel supply of high skill workers is unique. Today, Israel ranks third in the world in the number of university graduates per capita, after the United States and the Netherlands. It possesses the highest per capita number of scientists in the world, with 135 for every 10,000 citizens (compared to 85 per 10,000 in the United States), and publishes the highest number of scientific papers per capita. However, brain drain in academia is exceptionally high. Ban David (2008) demonstrates how differences between universities are inducing a massive academic migration from Israel to the United States. The magnitude of this scholarly brain drain is unparalleled in the western world. (See Figures 1 and 2). European Commission (2003) reported that 73\% of the 15,000 Europeans who studied for their PhD in the States between 1991 and 2000 plan to remain 
in America. If Europeans are concerned about the migration of their academics to the States, then Israelis should be nothing less than alarmed.

Figure 2: Israelis in Top American Departments, 2007, as percent senior faculty in Israel, by field

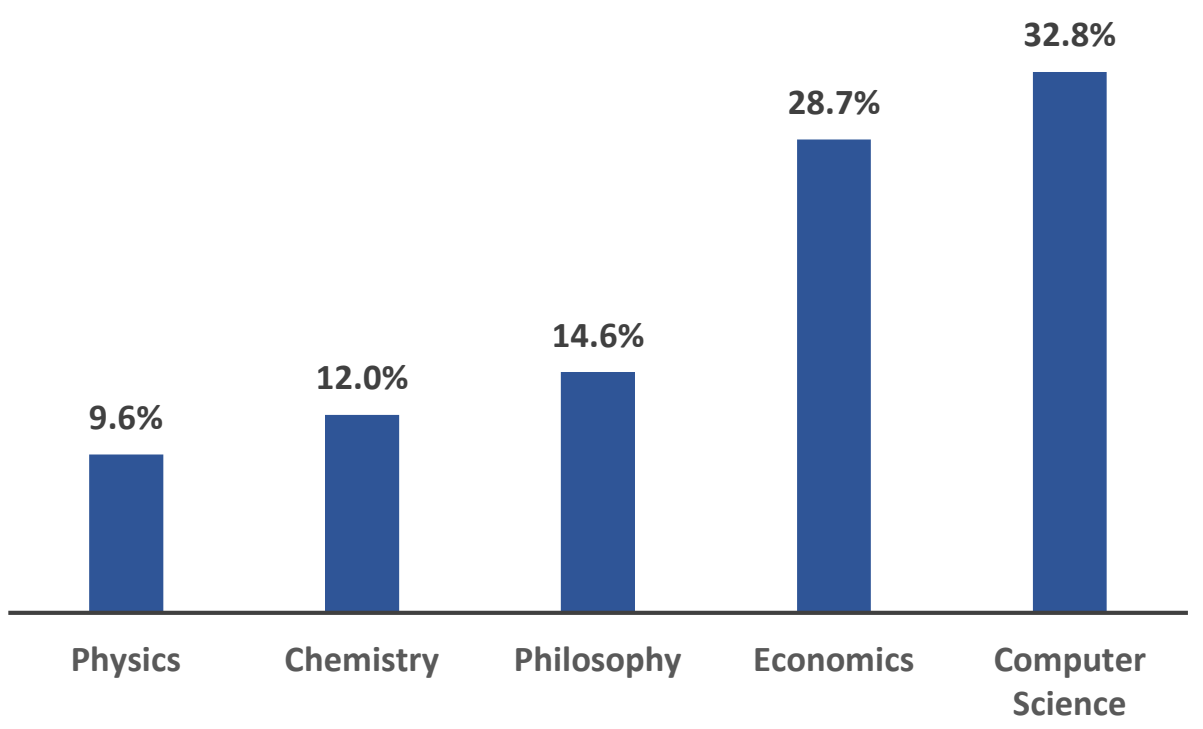

Source: Ban David (2007).

Figure 2 demonstrate that Israel stands out internationally in terms of the size and quality of the brain drain.

\section{Conclusion}

Even though the overall education attainment level of Israel (native born) labor force is highly ranked currently, schooling gaps develop. Israel, currently, has below average school gap among advanced economies. A test score of 4.686 compared to the group average 4.939. See Table 9.1. 
Table 4: Test Scores

\begin{tabular}{|c|c|c|c|c|c|}
\hline \multicolumn{2}{|c|}{ EUR } & \multicolumn{2}{|c|}{ DC } & \multicolumn{2}{|c|}{ LDC } \\
\hline Country & EQ & Country & EQ & Country & EQ \\
\hline Austria & 5.089 & Australia & 5.094 & Argentina & 3.920 \\
\hline Belgium & 5.041 & Canada & 5.038 & Brazil & 3.638 \\
\hline Switzerland & 5.142 & Hong Kong & 5.195 & Chile & 4.049 \\
\hline Denmark & 4.962 & Israel & 4.686 & China & 4.939 \\
\hline Spain & 4.829 & Japan & 5.310 & Colombia & 4.152 \\
\hline Finland & 5.126 & Korea, Rep. & 5.338 & Egypt & 4.030 \\
\hline France & 5.040 & New Zealand & 4.978 & Indonesia & 3.880 \\
\hline $\begin{array}{c}\text { United } \\
\text { Kingdom }\end{array}$ & 4.950 & Singapore & 5.330 & India & 4.281 \\
\hline Germany & 4.956 & $\begin{array}{c}\text { Taiwan (Chinese } \\
\text { Taipei) }\end{array}$ & 5.452 & Iran & 4.219 \\
\hline Greece & 4.608 & United States & 4.903 & Jordan & 4.264 \\
\hline Ireland & 4.995 & & & Lebanon & 3.950 \\
\hline Italy & 4.758 & & & Morocco & 3.327 \\
\hline Netherlands & 5.115 & & & Mexico & 3.998 \\
\hline Norway & 4.830 & & & Malaysia & 4.838 \\
\hline Portugal & 4.564 & & & Nigeria & 4.154 \\
\hline Sweden & 5.013 & & & Peru & 3.125 \\
\hline & & & & Philippines & 3.647 \\
\hline & & & & Thailand & 4.565 \\
\hline & & & & Tunisia & 3.795 \\
\hline & & & & Turkey & 4.128 \\
\hline & & & & South Africa & 3.089 \\
\hline $\begin{array}{c}\text { Group } \\
\text { Averages }\end{array}$ & 4.939 & & 5.132 & & 3.999 \\
\hline
\end{tabular}

Notes: $\mathrm{EQ}=$ average test score in mathematics and science, primary through end of secondary school, all years (scaled to PISA scale divided by 100).

Source: OECD Library.

Notwithstanding Israel's current technological and scientific prowess, top-talent drain has been trending upward. 


\section{Appendix A: Immigrant Skill Composition: Robustness Tests}

Razin and Wahba (2015) utilize the free labor movement within the European Union plus Norway and Switzerland (EUROPE) and the restricted movement from outside the EUROPE in order to compare the free-migration regime to the controlled-migration regime. Using bilateral migration movements, and splitting the sample among flows within EUROPE, and flows from outside EUROPE, they identify in Table 1 the migration regime effect. Robustness tests are shown in Tables A2-A4. The dependent variable is the share of skilled migrants in the migrant population, and the main explanatory variable is "benefits per capita" -a measure of the generosity of the welfare state. The hypothesis is that under free migration the coefficient of this variable is negative whereas under controlled migration coefficient of "benefits per capita multiplied by $R$ " is positive. The indicator $X$ is a dummy variable: $R=1$, if migration is controlled, whereas $\mathrm{R}=0$, if migration is free. Recall the bi lateral migration flows within EUROPE are referred to as free migration, whereas bilateral migration flows where the SOURCE is outside and the DESTINATION is inside EUROPE are referred to as controlled migration. 
Table A2: OLS Estimates Using Migration Rates Adjusted by Relative Educational Quality Dependent Variable: Skill Difference in Migration (REQ) Rates in 2000

\begin{tabular}{|c|c|c|c|c|c|c|}
\hline & \multicolumn{3}{|c|}{$\begin{array}{c}\text { EUR \& DC } \\
\text { to EUR }\end{array}$} & \multicolumn{3}{|c|}{$\begin{array}{l}\text { EUR \& LDC } \\
\text { to EUR }\end{array}$} \\
\hline Welfare generosity & & & & & & \\
\hline $\begin{array}{l}\text { benefits per capita } \\
\text { (logs) } 1974-90 \\
\text { (host) }\end{array}$ & $\begin{array}{l}-0.105 \\
(0.052)^{* *}\end{array}$ & $\begin{array}{l}-0.115 \\
(0.049)^{*} \\
*\end{array}$ & $\begin{array}{l}-0.109 \\
(0.042)^{*} \\
*\end{array}$ & $\begin{array}{l}-0.111 \\
(0.051)^{*} \\
*\end{array}$ & $\begin{array}{l}-0.116 \\
(0.054)^{*} \\
*\end{array}$ & $\begin{array}{l}-0.138 \\
(0.054)^{*} \\
*\end{array}$ \\
\hline $\begin{array}{l}\text { benefits per capita } \\
\text { (logs) } \\
1974-90 \text { (host) X R }\end{array}$ & $\begin{array}{l}0.115 \\
(0.053)^{* *}\end{array}$ & $\begin{array}{l}0.139 \\
(0.062)^{*} \\
*\end{array}$ & $\begin{array}{l}0.135 \\
(0.054)^{*} \\
*\end{array}$ & $\begin{array}{l}0.104 \\
(0.059)^{*}\end{array}$ & $\begin{array}{l}0.111 \\
(0.070)\end{array}$ & $\begin{array}{l}0.132 \\
(0.062)^{*} \\
*\end{array}$ \\
\hline $\begin{array}{l}\text { Lagged migration } \\
\text { rates }\end{array}$ & & & & & & \\
\hline $\begin{array}{l}\text { low-skilled } \\
\text { migration } \\
\text { rate (REQ) } 1990\end{array}$ & $\begin{array}{l}-0.697 \\
(0.151)^{* *} \\
*\end{array}$ & $\begin{array}{l}-0.695 \\
(0.149)^{*} \\
* *\end{array}$ & $\begin{array}{l}-0.686 \\
(0.160)^{*} \\
* *\end{array}$ & $\begin{array}{l}-0.681 \\
(0.156)^{*} \\
* *\end{array}$ & $\begin{array}{l}-0.595 \\
(0.143)^{*} \\
* *\end{array}$ & $\begin{array}{l}-0.578 \\
(0.150)^{*} \\
* *\end{array}$ \\
\hline $\begin{array}{l}\text { low-skilled } \\
\text { migration } \\
\text { rate (REQ) } 1990 \times \mathrm{R}\end{array}$ & $\begin{array}{l}1.711 \\
(0.175)^{* *} \\
*\end{array}$ & $\begin{array}{l}1.738 \\
(0.172)^{*} \\
* *\end{array}$ & $\begin{array}{l}1.713 \\
(0.174)^{*} \\
* *\end{array}$ & $\begin{array}{l}0.715 \\
(0.295)^{*} \\
*\end{array}$ & $\begin{array}{l}0.576 \\
(0.217)^{*} \\
* *\end{array}$ & $\begin{array}{l}0.314 \\
(0.208)\end{array}$ \\
\hline $\begin{array}{l}\text { high-skilled } \\
\text { migration }\end{array}$ & $\begin{array}{l}1.037 \\
(0.169)^{* *} \\
*\end{array}$ & $\begin{array}{l}1.033 \\
(0.168)^{*} \\
* *\end{array}$ & $\begin{array}{l}1.022 \\
(0.176)^{*} \\
* *\end{array}$ & $\begin{array}{l}1.011 \\
(0.175)^{*} \\
* *\end{array}$ & $\begin{array}{l}0.937 \\
(0.162)^{*} \\
* *\end{array}$ & $\begin{array}{l}0.920 \\
(0.167)^{*} \\
* *\end{array}$ \\
\hline $\begin{array}{l}\text { high-skilled } \\
\text { migration } \\
\text { rate (REQ) } 1990 \times \mathrm{R}\end{array}$ & $\begin{array}{l}-0.702 \\
(0.167)^{* *}\end{array}$ & $\begin{array}{l}-0.702 \\
(0.164)^{*}\end{array}$ & $\begin{array}{l}-0.688 \\
(0.171)^{*}\end{array}$ & $\begin{array}{l}-0.584 \\
(0.194)^{*}\end{array}$ & $\begin{array}{l}-0.637 \\
(0.175)^{*}\end{array}$ & $\begin{array}{l}-0.468 \\
(0.178)^{*}\end{array}$ \\
\hline
\end{tabular}




\begin{tabular}{|c|c|c|c|c|c|}
\hline & $* *$ & $* *$ & $* *$ & $* *$ & ** \\
\hline Returns to skills & & & & & \\
\hline $\begin{array}{l}\text { high-low labor ratio } \\
\text { in } \\
1990 \text { - (host) }\end{array}$ & $\begin{array}{l}-0.482 \\
(0.234)^{*} \\
*\end{array}$ & & & $\begin{array}{l}0.205 \\
(0.302)\end{array}$ & \\
\hline $\begin{array}{l}\text { high-low labor ratio } \\
\text { in } \\
1990 \text { (host) X R }\end{array}$ & $\begin{array}{l}0.325 \\
(0.482)\end{array}$ & & & $\begin{array}{l}0.043 \\
(0.571)\end{array}$ & \\
\hline $\begin{array}{l}\text { high-low wage diff. } \\
\text { in } \\
1995 \text { - (host) }\end{array}$ & & $\begin{array}{l}0.002 \\
(0.002)\end{array}$ & & & $\begin{array}{l}0.003 \\
(0.003)\end{array}$ \\
\hline $\begin{array}{l}\text { high-low wage diff. } \\
\text { in } \\
1995 \text { (host) X R }\end{array}$ & & $\begin{array}{l}-0.007 \\
(0.003)^{*} \\
*\end{array}$ & & & $\begin{array}{l}-0.006 \\
(0.003)^{*}\end{array}$ \\
\hline $\begin{array}{l}\text { Gini in } 1990 \\
\text { (source) }\end{array}$ & $\begin{array}{l}0.013 \\
(0.004)^{*} \\
* *\end{array}$ & $\begin{array}{l}0.014 \\
(0.004)^{*} \\
* *\end{array}$ & & $\begin{array}{l}0.011 \\
(0.004)^{*} \\
* *\end{array}$ & $\begin{array}{l}0.013 \\
(0.005)^{*} \\
* *\end{array}$ \\
\hline $\begin{array}{l}\text { Gini in } 1990 \\
\text { (source) } \\
\text { X R }\end{array}$ & $\begin{array}{l}-0.013 \\
(0.005)^{*} \\
* *\end{array}$ & $\begin{array}{l}-0.014 \\
(0.005)^{*} \\
* *\end{array}$ & & $\begin{array}{l}-0.011 \\
(0.005)^{*} \\
*\end{array}$ & $\begin{array}{l}-0.011 \\
(0.005)^{*} \\
*\end{array}$ \\
\hline $\begin{array}{l}\text { High-low unemp. } \\
\text { rate } \\
\text { diff. in } 1990 \text { - (host) }\end{array}$ & & $\begin{array}{l}0.001 \\
(0.002)\end{array}$ & & $\begin{array}{l}0.001 \\
(0.002)\end{array}$ & $\begin{array}{l}0.006 \\
(0.004)\end{array}$ \\
\hline $\begin{array}{l}\text { High-low unemp. } \\
\text { rate }\end{array}$ & & \begin{tabular}{|l|}
-0.004 \\
\end{tabular} & & -0.005 & \begin{tabular}{|l|}
-0.009 \\
\end{tabular} \\
\hline
\end{tabular}




\begin{tabular}{|l|l|l|l|l|l|l|}
$\begin{array}{l}\text { diff. in } 1990 \text { (host) } \\
\text { X R }\end{array}$ & & & $(0.004)$ & & $(0.004)$ & $(0.005)^{*}$ \\
\hline $\begin{array}{l}\text { Immigration } \\
\text { policies }\end{array}$ & & & & & & \\
\hline $\begin{array}{l}\text { Total migrant stock } \\
\text { in 1990 }\end{array}$ & $\begin{array}{l}-0.001 \\
(0.001)\end{array}$ & $\begin{array}{l}-0.001 \\
(0.001)\end{array}$ & $\begin{array}{l}-0.001 \\
(0.001)\end{array}$ & $\begin{array}{l}-0.001 \\
(0.001)\end{array}$ & $\begin{array}{l}-0.002 \\
(0.001)^{*} \\
* *\end{array}$ & $\begin{array}{l}-0.002 \\
(0.001)^{*} \\
*\end{array}$ \\
\hline $\begin{array}{l}\text { Share of refugees in } \\
1990\end{array}$ & -1.907 & -1.168 & -3.680 & -0.672 & -2.954 & -1.497 \\
\hline Observations & $(2.547)$ & $(3.230)$ & $(3.298)$ & $(1.983)$ & $(2.509)$ & $(3.081)$ \\
\hline R-squared & 384 & 384 & 360 & 569 & 569 & 533 \\
\hline N & 0.861 & 0.867 & 0.871 & 0.842 & 0.816 & 0.835 \\
\hline
\end{tabular}

Notes: All the migration rates are adjusted for the quality of education by the relative education quality in source to host country, i.e. $R E Q=\left(E Q_{s} / \mathrm{EQ}_{h}\right) ; \mathrm{F}=$ Free migration; $\mathrm{R}=$ Restricted migration. Regressions include log distance, dummy for same language in host and source, strong dummy between host and source, and real GDP per capita in host and in source countries. Robust standard errors in parentheses; * significant at 10\%; ** significant at 5\%; *** significant at $1 \%$. 
Table 8A3: IV Estimates with Lagged Dependent Variable

Dependent Variable: Skill Difference in Migration Rates in 2000

\begin{tabular}{|c|c|c|c|c|c|c|}
\hline & \multicolumn{3}{|c|}{$\begin{array}{c}\text { EUR \& DC } \\
\text { to EUR }\end{array}$} & \multicolumn{3}{|c|}{$\begin{array}{c}\text { EUR \& LDC } \\
\text { to EUR }\end{array}$} \\
\hline $\begin{array}{l}\text { Welfare } \\
\text { generosity }\end{array}$ & & & & & & \\
\hline $\begin{array}{l}\text { Fitted } \\
\text { benefits per } \\
\text { capita } \\
\text { (logs) 1974- } \\
90 \text { (host) }\end{array}$ & $\begin{array}{l}-0.157 \\
(0.081)^{*}\end{array}$ & $\begin{array}{l}-0.217 \\
(0.097)^{* *}\end{array}$ & $\begin{array}{l}-0.118 \\
(0.063)^{*}\end{array}$ & $\begin{array}{l}-0.181 \\
(0.080)^{* *}\end{array}$ & $\begin{array}{l}-0.180 \\
(0.089)^{* *}\end{array}$ & $\begin{array}{l}-0.154 \\
(0.070)^{* *}\end{array}$ \\
\hline $\begin{array}{l}\text { Fitted } \\
\text { benefits per } \\
\text { capita } \\
\text { (logs) 1974- } \\
90 \text { (host) X } \\
\text { R }\end{array}$ & $\begin{array}{l}0.270 \\
(0.089)^{* * * *}\end{array}$ & $\begin{array}{l}0.261 \\
(0.099)^{* * *}\end{array}$ & $\begin{array}{l}0.207 \\
(0.078)^{* * *}\end{array}$ & $\begin{array}{l}0.198 \\
(0.088)^{* *}\end{array}$ & $\begin{array}{l}0.209 \\
(0.103)^{* *}\end{array}$ & $\begin{array}{l}0.161 \\
(0.083)^{*}\end{array}$ \\
\hline $\begin{array}{l}\text { Lagged } \\
\text { migration } \\
\text { rates }\end{array}$ & & & & & & \\
\hline $\begin{array}{l}\text { low-skilled } \\
\text { migration } \\
\text { rate } 1990\end{array}$ & $\begin{array}{l}-0.711 \\
(0.130)^{* * *}\end{array}$ & $\begin{array}{l}-0.711 \\
(0.125)^{* * *}\end{array}$ & $\begin{array}{l}-0.706 \\
(0.135)^{* * *}\end{array}$ & $\begin{array}{l}-0.592 \\
(0.131)^{* * *}\end{array}$ & $\begin{array}{l}-0.581 \\
(0.131)^{* * *}\end{array}$ & $\begin{array}{l}-0.581 \\
(0.137)^{* * *}\end{array}$ \\
\hline $\begin{array}{l}\text { low-skilled } \\
\text { migration } \\
\text { rate } 1990 \mathrm{x} \\
\mathrm{R}\end{array}$ & $\begin{array}{l}1.774 \\
(0.171)^{* * *}\end{array}$ & $\begin{array}{l}1.775 \\
(0.166)^{* * *}\end{array}$ & $\begin{array}{l}1.752 \\
(0.169)^{* * *}\end{array}$ & $\begin{array}{l}0.563 \\
(0.229)^{* *}\end{array}$ & $\begin{array}{l}0.556 \\
(0.229)^{* *}\end{array}$ & $\begin{array}{l}0.562 \\
(0.221)^{* *}\end{array}$ \\
\hline $\begin{array}{l}\text { high-skilled } \\
\text { migration }\end{array}$ & 1.055 & 1.052 & 1.046 & 0.944 & 0.931 & 0.933 \\
\hline
\end{tabular}




\begin{tabular}{|c|c|c|c|c|c|c|}
\hline rate 1990 & $(0.147)^{* * *}$ & $(0.142)^{* * *}$ & $(0.150)^{* * *}$ & $(0.148)^{* * *}$ & $(0.148)^{* * *}$ & $(0.152)^{* * *}$ \\
\hline $\begin{array}{l}\text { high-skilled } \\
\text { migration } \\
\text { rate } 1990 \mathrm{x} \\
\mathrm{R}\end{array}$ & $\begin{array}{l}-0.726 \\
(0.147)^{* * *}\end{array}$ & $\begin{array}{l}-0.722 \\
(0.141)^{* * *}\end{array}$ & $\begin{array}{l}-0.713 \\
(0.148)^{* * * *}\end{array}$ & $\begin{array}{l}-0.627 \\
(0.166)^{* * *}\end{array}$ & $\begin{array}{l}-0.611 \\
(0.168)^{* * *}\end{array}$ & $\begin{array}{l}-0.618 \\
(0.168)^{* * *}\end{array}$ \\
\hline $\begin{array}{l}\text { Returns to } \\
\text { skills }\end{array}$ & & & & & & \\
\hline $\begin{array}{l}\text { high-low } \\
\text { labor ratio in } \\
1990 \text { - (host) }\end{array}$ & & $\begin{array}{l}-1.455 \\
(0.541)^{* * *}\end{array}$ & & & $\begin{array}{l}0.060 \\
(0.458)\end{array}$ & \\
\hline $\begin{array}{l}\text { high-low } \\
\text { labor ratio in } \\
1990 \text { (host) } \\
\text { X F }\end{array}$ & & $\begin{array}{l}0.794 \\
(0.548)\end{array}$ & & & $\begin{array}{l}0.522 \\
(0.690)\end{array}$ & \\
\hline $\begin{array}{l}\text { high-low } \\
\text { wage diff. in } \\
1995 \text { (host) }\end{array}$ & & & $\begin{array}{l}0.003 \\
(0.002)\end{array}$ & & & $\begin{array}{l}0.003 \\
(0.003)\end{array}$ \\
\hline $\begin{array}{l}\text { high-low } \\
\text { wage diff. in } \\
1995 \text { - (host) } \\
\text { X F }\end{array}$ & & & $\begin{array}{l}-0.008 \\
(0.003)^{* * * *}\end{array}$ & & & $\begin{array}{l}-0.006 \\
(0.003)^{*}\end{array}$ \\
\hline $\begin{array}{l}\text { Gini in } 1990 \\
\text { (source) }\end{array}$ & & $\begin{array}{l}0.012 \\
(0.004)^{* * *}\end{array}$ & $\begin{array}{l}0.012 \\
(0.004)^{* * * *}\end{array}$ & & $\begin{array}{l}0.011 \\
(0.004)^{* * *}\end{array}$ & $\begin{array}{l}0.011 \\
(0.004)^{* *}\end{array}$ \\
\hline $\begin{array}{l}\text { Gini in } 1990 \\
\text { (source) X R }\end{array}$ & & $\begin{array}{l}-0.013 \\
(0.005)^{* * *}\end{array}$ & $\begin{array}{l}-0.015 \\
(0.005)^{* * * *}\end{array}$ & & $\begin{array}{l}-0.010 \\
(0.005)^{* *}\end{array}$ & $\begin{array}{l}-0.010 \\
(0.005)^{* *}\end{array}$ \\
\hline $\begin{array}{l}\text { High-low } \\
\text { unemp. rate }\end{array}$ & & 0.011 & -0.000 & & 0.005 & 0.005 \\
\hline
\end{tabular}




\begin{tabular}{|c|c|c|c|c|c|c|}
\hline $\begin{array}{l}\text { diff. } 1990 \\
\text { (host) }\end{array}$ & & $(0.005)$ & $(0.002)$ & & $(0.003)$ & $(0.004)$ \\
\hline $\begin{array}{l}\text { High-low } \\
\text { unemp. rate } \\
\text { diff. } 1990 \text { - } \\
\text { (host) X F }\end{array}$ & & $\begin{array}{l}-0.005 \\
(0.005)\end{array}$ & $\begin{array}{l}-0.005 \\
(0.004)\end{array}$ & & $\begin{array}{l}-0.008 \\
(0.006)\end{array}$ & $\begin{array}{l}-0.008 \\
(0.005)^{*}\end{array}$ \\
\hline $\begin{array}{l}\text { Immigration } \\
\text { policies }\end{array}$ & & & & & & \\
\hline $\begin{array}{l}\text { Total } \\
\text { migrant } \\
\text { stock } \\
\text { in } 1990\end{array}$ & $\begin{array}{l}-0.001 \\
(0.001)\end{array}$ & $\begin{array}{l}-0.001 \\
(0.001)\end{array}$ & $\begin{array}{l}-0.001 \\
\\
(0.001)\end{array}$ & $\begin{array}{l}-0.002 \\
(0.001)^{* * * *}\end{array}$ & $\begin{array}{l}-0.003 \\
(0.001)^{* * *}\end{array}$ & $\begin{array}{l}-0.003 \\
(0.001)^{* *}\end{array}$ \\
\hline $\begin{array}{l}\text { Share of } \\
\text { refugees in } \\
1990\end{array}$ & $\begin{array}{l}-2.470 \\
(3.174)\end{array}$ & $\begin{array}{l}0.827 \\
(3.803)\end{array}$ & $\begin{array}{l}-4.835 \\
\\
(3.670)\end{array}$ & $\begin{array}{l}-1.590 \\
(2.603)\end{array}$ & $\begin{array}{l}-2.990 \\
(2.827)\end{array}$ & $\begin{array}{l}-2.261 \\
(3.266)\end{array}$ \\
\hline $\begin{array}{l}\text { Cragg- } \\
\text { Donald F- } \\
\text { statistics }\end{array}$ & 49.46 & 54.34 & 103.01 & 86.23 & 98.44 & 159.12 \\
\hline Observations & 384 & 384 & 360 & 538 & 538 & 504 \\
\hline R-squared & 0.865 & 0.871 & 0.875 & 0.811 & 0.815 & 0.821 \\
\hline
\end{tabular}

Notes: $\mathrm{F}=$ Free migration; $\mathrm{R}=$ Restricted migration. Instrumented using legal origin dummies, and the interaction of legal origin dummies and R. Regressions include real GDP per capita growth rate in host, log distance, dummy for same language in host and source, strong dummy between host and source, and real GDP per capita in host and in source countries.

Robust standard errors in parentheses; * significant at 10\%; ** significant at 5\%; *** significant at $1 \%$. 
Table A4: IV Estimates with Lagged Dependent Variable and Adjusted by Relative Educational Quality (REQ)

Dependent Variable: Skill Difference in Migration Rates (REQ) in 2000

\begin{tabular}{|c|c|c|c|c|c|c|}
\hline \multirow[b]{2}{*}{ Welfare generosity } & \multicolumn{3}{|c|}{$\begin{array}{c}\text { EUR \& DC } \\
\text { to EUR }\end{array}$} & \multicolumn{3}{|c|}{$\begin{array}{c}\text { EUR \& LDC } \\
\text { to EUR }\end{array}$} \\
\hline & & & & & & \\
\hline $\begin{array}{l}\text { Fitted benefits per } \\
\text { capita } \\
\text { (logs) } 1974-90 \text { (host) }\end{array}$ & $\begin{array}{l}-0.159 \\
(0.075)^{*} \\
*\end{array}$ & $\begin{array}{l}-0.207 \\
(0.087)^{*} \\
*\end{array}$ & $\begin{array}{l}-0.170 \\
(0.070)^{*} \\
*\end{array}$ & $\begin{array}{l}-0.175 \\
(0.076)^{*} \\
*\end{array}$ & $\begin{array}{l}-0.179 \\
(0.079)^{*} \\
*\end{array}$ & $\begin{array}{l}-0.178 \\
(0.064)^{*} \\
* *\end{array}$ \\
\hline $\begin{array}{l}\text { Fitted benefits per } \\
\text { capita } \\
(\operatorname{logs}) 1974-90 \text { (host) X } \\
\text { R }\end{array}$ & $\begin{array}{l}0.269 \\
(0.089)^{*} \\
* *\end{array}$ & $\begin{array}{l}0.268 \\
(0.098) * \\
* *\end{array}$ & $\begin{array}{l}0.207 \\
(0.077)^{*} \\
* *\end{array}$ & $\begin{array}{l}0.207 \\
(0.083)^{*} \\
*\end{array}$ & $\begin{array}{l}0.218 \\
(0.102)^{*} \\
*\end{array}$ & $\begin{array}{l}0.194 \\
(0.080)^{*} \\
*\end{array}$ \\
\hline $\begin{array}{l}\text { Lagged migration } \\
\text { rates }\end{array}$ & & & & & & \\
\hline $\begin{array}{l}\text { low-skilled migration } \\
\text { rate (REQ) } 1990\end{array}$ & $\begin{array}{l}-0.686 \\
(0.148)^{*} \\
* *\end{array}$ & $\begin{array}{l}-0.685 \\
(0.145)^{*} \\
* *\end{array}$ & $\begin{array}{l}-0.678 \\
(0.155)^{*} \\
* *\end{array}$ & $\begin{array}{l}-0.602 \\
(0.144)^{*} \\
* *\end{array}$ & $\begin{array}{l}-0.665 \\
(0.154)^{*} \\
* *\end{array}$ & $\begin{array}{l}-0.666 \\
(0.164)^{*} \\
* *\end{array}$ \\
\hline $\begin{array}{l}\text { low-skilled migration } \\
\text { rate (REQ) } 1990 \times \mathrm{R}\end{array}$ & $\begin{array}{l}1.753 \\
(0.172)^{*} \\
* *\end{array}$ & $\begin{array}{l}1.765 \\
(0.170)^{*} \\
* *\end{array}$ & $\begin{array}{l}1.732 \\
(0.174)^{*} \\
* *\end{array}$ & $\begin{array}{l}0.553 \\
(0.212)^{*} \\
* *\end{array}$ & $\begin{array}{l}0.694 \\
(0.290)^{*} \\
*\end{array}$ & $\begin{array}{l}0.686 \\
(0.292)^{*} \\
*\end{array}$ \\
\hline $\begin{array}{l}\text { high-skilled migration } \\
\text { rate (REQ) } 1990\end{array}$ & $\begin{array}{l}1.026 \\
(0.166)^{*} \\
* *\end{array}$ & $\begin{array}{l}1.022 \\
(0.163)^{*} \\
* *\end{array}$ & $\begin{array}{l}1.014 \\
(0.171)^{*} \\
* *\end{array}$ & $\begin{array}{l}0.941 \\
(0.163)^{*} \\
* *\end{array}$ & $\begin{array}{l}0.991 \\
(0.173)^{*} \\
* *\end{array}$ & $\begin{array}{l}0.989 \\
(0.180)^{*} \\
* *\end{array}$ \\
\hline $\begin{array}{l}\text { high-skilled migration } \\
\text { rate (REQ) } 1990 \text { x R }\end{array}$ & $\begin{array}{l}-0.698 \\
(0.164)^{*} \\
* *\end{array}$ & $\begin{array}{l}-0.693 \\
(0.162)^{*} \\
* *\end{array}$ & $\begin{array}{l}-0.684 \\
(0.168)^{*} \\
* *\end{array}$ & $\begin{array}{l}-0.632 \\
(0.173)^{*} \\
* *\end{array}$ & \begin{tabular}{|l|}
-0.566 \\
$(0.193) *$ \\
$* *$
\end{tabular} & $\begin{array}{l}-0.564 \\
(0.198)^{*} \\
* *\end{array}$ \\
\hline & & & & & & \\
\hline
\end{tabular}




\begin{tabular}{|c|c|c|c|c|c|c|}
\hline $\begin{array}{l}\text { high-low labor ratio in } \\
1990 \text { - (host) }\end{array}$ & & $\begin{array}{l}-1.192 \\
(0.358)^{*} \\
* *\end{array}$ & & & $\begin{array}{l}0.075 \\
(0.386)\end{array}$ & \\
\hline $\begin{array}{l}\text { high-low labor ratio in } \\
1990 \text { (host) X R }\end{array}$ & & $\begin{array}{l}0.833 \\
(0.534)\end{array}$ & & & $\begin{array}{l}0.027 \\
(0.574)\end{array}$ & \\
\hline $\begin{array}{l}\text { high-low wage diff. in } \\
1995 \text { (host) }\end{array}$ & & & $\begin{array}{l}0.004 \\
(0.002)^{*}\end{array}$ & & & $\begin{array}{l}0.003 \\
(0.002)\end{array}$ \\
\hline $\begin{array}{l}\text { high-low wage diff. in } \\
1995 \text { - (host) X R }\end{array}$ & & & $\begin{array}{l}-0.007 \\
(0.003)^{*} \\
*\end{array}$ & & & $\begin{array}{l}-0.007 \\
(0.005)^{*} \\
*\end{array}$ \\
\hline Gini in 1990 (source) & & $\begin{array}{l}0.012 \\
(0.004)^{*} \\
* *\end{array}$ & $\begin{array}{l}0.013 \\
(0.004)^{*} \\
* *\end{array}$ & & $\begin{array}{l}0.012 \\
(0.004)^{*} \\
* *\end{array}$ & $\begin{array}{l}0.013 \\
(0.005)^{*} \\
* *\end{array}$ \\
\hline $\begin{array}{l}\text { Gini in } 1990 \text { (source) } \mathrm{X} \\
\mathrm{R}\end{array}$ & & $\begin{array}{l}-0.013 \\
(0.005)^{*} \\
* *\end{array}$ & $\begin{array}{l}-0.015 \\
(0.005)^{*} \\
* *\end{array}$ & & $\begin{array}{l}-0.012 \\
(0.004)^{*} \\
* *\end{array}$ & $\begin{array}{l}-0.012 \\
(0.004)^{*} \\
* *\end{array}$ \\
\hline $\begin{array}{l}\text { High-low unemp. rate } \\
\text { diff. } \\
\text { in } 1990 \text { (host) }\end{array}$ & & $\begin{array}{l}0.008 \\
(0.003)^{*} \\
*\end{array}$ & $\begin{array}{l}0.002 \\
(0.003)\end{array}$ & & $\begin{array}{l}0.003 \\
(0.003)\end{array}$ & $\begin{array}{l}0.006 \\
(0.004)\end{array}$ \\
\hline $\begin{array}{l}\text { High-low unemp. rate } \\
\text { diff. } \\
\text { in } 1990 \text { - (host) X R }\end{array}$ & & $\begin{array}{l}-0.005 \\
(0.005)\end{array}$ & $\begin{array}{l}-0.005 \\
(0.004)\end{array}$ & & $\begin{array}{l}-0.008 \\
(0.005)\end{array}$ & $\begin{array}{l}-0.012 \\
(0.004)^{*} \\
* *\end{array}$ \\
\hline Immigration policies & & & & & & \\
\hline $\begin{array}{l}\text { Total migrant stock in } \\
1990\end{array}$ & $\begin{array}{l}-0.001 \\
(0.001)\end{array}$ & $\begin{array}{l}-0.001 \\
(0.001)\end{array}$ & $\begin{array}{l}-0.001 \\
(0.001)\end{array}$ & $\begin{array}{l}-0.002 \\
(0.001)^{*}\end{array}$ & $\begin{array}{l}-0.001 \\
(0.001)\end{array}$ & $\begin{array}{l}-0.001 \\
(0.001)\end{array}$ \\
\hline
\end{tabular}




\begin{tabular}{|l|l|l|l|l|l|l|} 
& & & & $*$ & & \\
\hline $\begin{array}{l}\text { Share of refugees in } \\
1990\end{array}$ & -2.592 & 0.106 & -2.809 & -1.768 & -1.694 & -1.315 \\
\hline $\begin{array}{l}\text { Cragg-Donald F- } \\
\text { statistics }\end{array}$ & 51.69 & 58.98 & 62.65 & 86.45 & 92.77 & 169.49 \\
\hline Observations & 384 & 384 & 360 & 538 & 569 & 533 \\
\hline R-squared & 0.863 & 0.867 & 0.871 & 0.805 & 0.830 & 0.835 \\
\hline
\end{tabular}

Notes: All the migration rates are adjusted for the quality of education by relative quality in source to host, i.e. $R E Q=\left(E Q_{s} / \mathrm{EQ}_{h}\right), \mathrm{F}=$ Free migration; $\mathrm{R}=$ Restricted migration. Instrumented using legal origin dummies, and the interaction of legal origin dummies and R. Regressions include real GDP per capita growth rate in host, log distance, dummy for same language in host and source, strong dummy between host and source, and real GDP per capita in host and in source countries. Robust standard errors in parentheses; * significant at 10\%; ** significant at $5 \%$; *** significant at $1 \%$.

Table A2-A4 describe the skill mix-benefit correlations under various econometric specifications. Overall, the fiscal burden and the magnet hypotheses, tested with the coefficient of social benefit in the regressions, are statistically significant. Therefore, regression findings yield support for the magnet hypothesis under the free-migration regime, and to the fiscal burden hypothesis, under the restricted-migration regime. In the regression analysis Razin and Wahba (2015) control for differences in educational quality and returns to skills in source and host countries, and for endogeneity bias (by using instrumental variables). 


\section{References}

Ben-David, Dan (2007), “Soaring Minds: The Flight of Israel's Economists,” CEPR Discussion Paper No. 6338.

Ben-David, Dan (2008) “Brain Drained: Soaring Minds,” CEPR VOX,(March) http://voxeu.org/article/academic-exodus

Ben-David, Dan (2008), "Brain Drained: A Tale of Two Countries," CEPR Discussion Paper No. 6717.

Docquier, F. , O. Lohest and A. Marfouk (2005) "Brain drain in developing countries" Département des Sciences Économiques de l'Université catholique de Louvain Discussion Paper 2007-4. http://www.abdeslammarfouk.com/uploads/1/6/3/4/16347570/bddc.pdf.

European Commission (2003), "The Brain Drain to the US: Challenges and Answers."

Gould, Eric and Omer Moav (2007), “Israel's Brain Drain,” Israel Economic Review, Vol. 5, No. 1, pp. 1-22, 2007.

Hanson, Gordon H., And Matthew J. Slaughter, (2016), "High-Skilled Immigration and the Rise of STEM Occupations in US Employment,” NBER Working Paper No. 22623.

Kerr, Sari Pekkala, William Kerr, Çaglar Özden, and Christopher Parsons (2016) "Global Talent Flows," Journal of Economic Perspectives, Volume 30, Number 4,Fall 2016, Pages 3-30 http://krugman.blogs.nytimes.com/

Messina, Anthony M., (2007). The logics and politics of post-WWII migration to Western Europe. Cambridge: Cambridge University Press.

Peri, Giovanni (2005) "Determinants of Knowledge Flows and Their Effect on Innovation," Review of economics and Statistics, May 2005, Vol. 87, No. 2, Pages 308-322. 
Peri, Giovanni (2016), "Immigrants, Productivity, and Labor Markets," Journal of Economic Perspectives, Volume 30, Number 4, Fall 2016, Pages 3-30

Peri, Giovanni, Kevin Y. Shih, and Chad Sparber (2014) "Foreign STEM Workers and Native Wages and Employment in U.S. Cities,” NBER Working Paper No. 20093.

Razin, Assaf, and Efraim Sadka, (2014), Migration States and Welfare States: Why Is America Different from Europe?, Palgrave Pivot Series, Palgrave macmillan.

Razin, Assaf, Efraim Sadka, and Phillip Swagel (2002). "Tax Burden and Migration: A Political Economy Theory and Evidence.” Journal of Public Economics. 76 (September).

Razin, Assaf, and Jackline Wahba (2015) Vol "Welfare Magnet Hypothesis, Fiscal Burden, and Immigration Skill Selectivity"Scandinavian Journal of Economics, Volume 117, Issue 2, April, Pages 369-402 